\title{
Developing An Alternative Tourism In Buleleng: Needs Based Education And Public Capital
}

\author{
Nyoman Dini Andiani ${ }^{*}$, Ni Made Ary Widiastini2 ${ }^{2}$ \\ 1 Program D3 Perotelan, Fakultas Ekonomi, Universitas Pendidikan Ganesha \\ 2 Program D3 Perotelan, Fakultas Ekonomi, Universitas Pendidikan Ganesha
}

\begin{abstract}
Penelitian This research was conducted in order to understand a form of education that is based on the needs of the community through the use of a variety of capital that can be used in the development of tourism in Buleleng. This study uses ethnographic approach which is a culturalist approach and its emphasis on people's lives. This approach is used considering the culture comes from the community and maintained and implemented by the community. Data in this study were collected through observation and interviews. Moreover carried out literature to books, previous studies and articles that have relevance to the case examined in this study. The data processing is done qualitative descriptive narrative presented. In this case, the existence of regional capitals in Buleleng are very interesting to be known, understood and analyzed in depth in order to produce a model of sustainable tourism. The development of an area into a tourist attraction is not an easy matter. However, the government can work together with local communities to develop the existing tourism in the area, where the first step can be done by utilizing local labor in the area and to synergy between the needs of the community with programs implemented so that the common goal of improving the quality of tourism and social welfare can be achieved.
\end{abstract}

\section{Key Word:}

An alternative,

education, tourism

\section{Introduction}

Economically, tourism has unique position because tourism is not industry (although tourism develops many business that correlated \& depended to each other) but tourism is related to all aspects of economy in an area or a country. The impact of tourism involves skill sector, industry sector. In Indonesia, potency to develop tourism sector is unlimited. So that it needs the readiness and the improvement in all areas included the management and the development. Government has set tourist destinations in Indonesia, but actually there are many potential visits that can be developed and managed maximally, without harming other component. Because tourism activity is the combination between 3 main components such as actraction and destination, facility in the destination and accesibility in that destination. With the phenomena, tourism sector needs special planning that not only giving benefit economically but also involving the sustanaibility of environment phisically, because in planning we do not need strategy for non phisic but phisical environment needs to be emphasized crucially for tourism destination or area planning.

Tourism is actually a social phenomenon that involves human beings, society, and culture, but in the development of tourism is seen as an economic activity with the aim to provide benefits to various parties that the tourism businesses, governments and local communities are developed as a tourist destination. Ideally in the development of tourism, all parties should benefit both in terms of social , economic, cultural, and political environments, so the need for synergy between the management system and the development of sustainable kepariwisata. [1] Gee and Fayos Sola in Ardika (2007: 45 ) revealed three requirements of sustainable tourism management quality, sustainability (continuity) and balance. This is in Bali to do with coordination and synergy between the district and provincial governments, local communities, the tourism industry and tourists.

Alternative tourism is a solution in addressing the various issues arising from the development of tourism (mass tourism). As stated by [2] Moscardo in Christou (2012) as follows. 
"Alternative tourism crew rapidly and out of the need to remedy mass tourism's negatively impact on the environment and society, which could affect the attractiveness of a given destination from a long term prospective (Moscardo dalam Christou, 2012)".

Alternative tourism as described by Moscardo is a form of tourism that aims to improve the negative impact to the environment and society as a result of the development of mass tourism. Through the development of alternative tourism is expected potential of a region can be well managed and optimized so as to provide benefits in the long term for the next generation.

Tourism is actually a social phenomenon that involves human beings, society, and culture, but in the development of tourism is seen as an economic activity with the aim to provide benefits to various parties that the tourism businesses, governments and local communities are developed as a tourist destination. Ideally in the development of tourism, all parties should benefit both in terms of social, economic, cultural , and political environments , so the need for synergy between the management system and the development of sustainable kepariwisata. [1] Gee and Fayos Sola in Ardika (2007: 45 ) revealed three requirements of sustainable tourism management quality, sustainability (continuity) and balance. This is in Bali to do with coordination and synergy between the district and provincial governments, local communities, the tourism industry and tourists.

Society is a part that can not be separated from the development of an area into a tourist destination requires special attention. In this context, community participation is a must in any construction, so that the construction can continue. This is particularly true in the multidimensional development, and more specifically that the social dimension of development is very strong. Active community participation should also be noted, because in community activities will interact directly with tourists. In conjunction with the evolution of public attitudes towards tourists [3] Doxey in Shafaei and Mohamed (2015: 2) mentions a model of irindex (irritation index) that describes changes in local people's attitudes towards tourists linearly. First attitude - initially positive turns into negative along with the number of tourists. Stages - stages of people's attitudes tehadap local tourists are as follows: 1) Euphoria. Tourist arrivals are well received with an abundance of hope. This happened in the early phases of development of tourism in a tourist destination, and generally at tourist destinations that do not have a plan. 2) Apathy. Communities receive tourists for granted, and public relations with the tourists dominated by commercial relationships. Planning is done on a tourist destination in this phase generally only emphasizes the marketing aspect. 3) Annoyance. Has almost reached saturation point and people start to feel disturbed by the presence of tourists. Planning made generally trying to improve infrastructure and facilities, but there is no attempt to limit the growth. 4) antagonism. Society has openly demonstrated his displeasure, and see tourists as a source of problems. In this phase, planners realized the importance of a comprehensive plan.

Based on the irindex model proposed by [3] Doxey in Shafaei and Mohamed ( 2015 ) above , it is a good synergy between tourism actors with the private sector, government and the public certainly expected to provide a positive impact for the future development of tourism. Hence the need for action from the government in order to provide an understanding to the public about the importance of tourism , which in this case other than as a government regulator must also be able to mediate between tourism businesses with the community in the area of tourism as an important part. People can not be separated from the development of tourism in the region, have been often only included as a participant in tourism resulting lack economical benefits achieved as well as the degradation of the other fine capitals that social capital, cultural capital and environmental capital .

The local community is members of a group, whether it is large or small groups, living together in such a way that they feel that the group is able to meet the needs - the main purpose of life. Relationships and linkages community and tourism can be seen from two different sides, the side that can have a positive impact on society and which may have a negative impact. In order for the development of the tourism sector can be a positive impact for the community, then there are some things that should get consideration, among other things: 1) The development of the tourism sector / tourist areas should involve local communities (local community based tourism); 2) Tourism should be more addressed to the group-small groups and generally small-scale enterprises; 3 ) Tourism should emphasize the participation of local communities, including ownership and management, particularly for rural communities (Pitana, 2002).

Buleleng regency which is located in the northern area of the island has a lot of both natural and cultural potential that can be exploited, managed and packed into a tourist attraction. Addressing the problems faced in the Southern region of the island of Bali which occur as a result of the development of mass tourism, it should be a kind of tourism developed in Buleleng is an alternative tourism, by exploiting natural resources and cultural resources. Understanding the many unique and distinctive culture which is owned by the people of Buleleng, the development of alternative tourism through the utilizati on of 
cultural resources is a solution to make Buleleng as a tourist destination that is different from other tourist destinations in Bali.

Buleleng whose population is the mixture of various ethnic make people life to be very unique, even among ethnic acceptance has spawned various forms of social capital such as the multicultural temple in several places. Besides temples multicultural, Buleleng Regency also has other tourist attractions such as beaches, marine parks, lakes, waterfalls, hot springs, rivers, pretending that have historical value, monasteries, battle monuments, museum, library, traditional unique art, bamboo crafts, wood carving crafts, and ancient villages called Bali Aga. Through potential, certainly able to provide opportunities for the development of tourism in Buleleng particularly unique culture. The existence of regional capitals in Buleleng are very interesting to be known, understood and analyzed in depth in order to produce a model of sustainable tourism. This research was conducted in order to understand a form of education that is based on the needs of the community through the use of a variety of capital that can be used in the development of tourism in Buleleng.

\section{Method}

This study uses ethnographic approach which is a culturalist approach and its emphasis on people's lives. This approach is used considering the culture comes from the community and maintained and implemented by the community. Data in this study were collected through observation and interviews. Moreover carried out literature to books, previous studies and articles that have relevance to the case examined in this study. The data processing is done qualitative descriptive narrative presented.

\section{Results and Discussion}

Alternative tourism as tourism development as opposed to mass tourism has many differences which are considered alternative tourism and is expected to be a solution to address and rectify the negative effects resulting from mass tourism. As noted by [2] Smith and Eadington in Christou, 2012 as follows.

"The birth of alternative tourism was due to high criticism for mass tourism and its negative effects on destination areas. Alternative tourism incorporated soft tourism, small-scale tourism, green tourism, nature tourism and integrated tourism. Alternative tourism was used as a hope for proving consistency with natural, social and community values, as alternative tourism could have less negative effects on destination areas, environment and population without diminishing positive economic effects (Smith and Eadington dalam Christou, 2012)". Differences in mass tourism (mass tourism) and tourism alternative (Alternative tourism) can be seen in the following table.

Table 1. Mass Tourism Vs Alternatif Tourism

\begin{tabular}{lll}
\hline \multicolumn{1}{c}{ Mass Tourism } & \multicolumn{1}{c}{ Alternative Tourism } \\
\hline Feneral & Rapid development & Slow development \\
& Maximizes & Optimizes \\
& Socially, environmentally, & Socially, environmentally, considerate, \\
inconsiderate, aggressive & cautions \\
& Short term & Long term \\
& Remote control & Local control \\
& Unstable & Stable \\
Price consciousness & Value consciousness \\
& Quantitative & Qualitative \\
& Growth & Development \\
& Peak holiday periods, seasonal & Staggered holiday periods, no \\
& necessarily seasonal \\
& Capacity for high seasonal demand & Staggered holiday periods, no \\
& necessarily seasonal \\
& Tourism development everywhere & Development only in suitable places \\
& Large groups & Single, families, small groups \\
& Fixed program & Tourists directed \\
Spontaneous decisions & Tourist decide \\
Comfortable and passive & Demanding and active \\
\hline
\end{tabular}


Based on Table 1 of the difference in the shape and the type of tourists who are on mass tourism and alternative tourism can be seen clearly that the tourism alternative very concerned about the condition of a tourist destination. In this context alternative tourism is a tourism development activities are carried out slowly by taking into account various aspects that can be influenced by the development of tourism. Alternative tourism strongly emphasizes quality, which is of course different from the mass tourism that promotes quantity. Tourism sustainability for the next generation of highly considered in the development of alternative tourism, so it is very appropriate if Buleleng developed forms of tourism is the alternative tourism in this case utilizing resources in an optimal culture, not a maximum.

\section{General Preview of Buleleng Regency}

Alternative Tourism Development in Buleleng Based Society Cultural Resources

Based on the Bali Provincial Regulation No. 2 of 2012 stated that the type of tourism developed in Bali is cultural tourism. The explanation of cultural tourism referred to in the regulation are as follows. "Tourism Culture Bali is Bali tourism that is based on the culture of Bali which is implemented from the teachings of Hinduism and philosophy of Tri Hita Karana as the main potential by using tourism as a device for the actualization, to realize a dynamic mutual relationship between tourism and culture which makes them grow synergistic, harmonious and sustainable to provide welfare to the community, cultural and environmental sustainability (Bali Regulation No. 2 of 2012, Chapter I, Article 1, Points 14) ".

Understanding the content contained in Bali Perda number 2 of 2012, then implicitly the development of cultural tourism in Buleleng will have the support of various parties, especially of governance at the provincial level. Development of alternative tourism through the utilization of cultural potential in Buleleng is interesting to observe and apply, given in addition to having a lot of cultural resources, Buleleng great distance from the main entrance of the Ngurah Rai Airport should be able to develop tourism that is unique and different from existing tourism in other tourist destinations so that it will be the main attraction for tourists to come and stay in Buleleng.

Culture referred to in this article not only as an object, but more than that culture is something that is in people's lives and are liquid and allow it to adapt to changes, including tourism. As described by [4] Robinson and Picard (2006) on culture as follows. "Culture is a fluid and problematic concept to deal with. In this context it is summarily taken to mean both 'ways of life' (beliefs, values, social practices, rituals, and traditions etc.) and the tangible (building, monuments, objects etc.) and the intangible (language, performances and festivals, craftsmanship etc.) expressions and manifestations of society's values and beliefs. In a tourist sense, culture refers to both 'peoples' and their ordinary social characteristics, traditions and day to day patterns of behavior which mark them out as 'different', as well as to more exceptional representations of creative and artistic endeavor (Robinson dan Picard, 2006)".

Culture as something inseparable from public life, led to the development of cultural tourism as defined in Regulation number 2 of 2012 Bali implicitly include the community to be actively involved in tourism. Culture as defined by [4] Robinson and Picard (2006), such as beliefs, values, norms, language and other related to the life of society, the development of alternative tourism based on the cultural resources in Buleleng must involve an active role in society.

Realizing the importance of the community, it is necessary to approach with understanding the condition of the community and its resources. As noted [5] Adi (2012) that there are two methods of approach that can be applied in the development of community-based tourism. "(1) Approach directive carried out based on the assumption that the community worker knows what is needed and what is good for society. In this approach, the role of community workers predominates because of the initiative of the activities and resources needed comes from more of a community worker. In this case a community worker who define what is good or bad for society, for ways what needs to be done to fix it and then provide the means necessary for these improvements. With this approach, the initiative and the decision is in the hands penganbilan community worker; (2) non-directive approach (participatory) is performed based on the assumption that people know what they really need and what is good for them. In this new approach, community worker leading role in a changing society is the society itself, community worker is more probing and develop the potential of the community. The public is given the opportunity to make an analysis and make decisions for themselves that are useful for the purposes they want (Adi, 2012) " Through an approach consistent with the condition of the people, is expected to alternative tourism development that involves local communities as the host in the tourist destination actively to run well. Moreover, in its application is necessary to understand the socio-cultural capital such as educational background, skills and the strong relationship between the public and the elite, so that the chosen approach can be adapted to existing conditions in the community.

Buleleng regency has various types of cultural resources that as many as 54 cultural tourist attraction which consists of 42 site and 12 art atractions. The cultural resources are the Museum Gedong 
Kertya, Puri Agung Singaraja, Ex Buleleng Harbour, Tri Yudha Mandala Monument, Singa Ambara Raja Monument, Craftsman Dulang Petandakan, Naga Sepeha Village, Jinengdalem Village, Pengelatan Village, Beji temple, Pura Dalem Sangsit, Pura Dalem Jagaraga, Pura Meduwe Coral, Pura Subak Bebetin Village, Pura Yeh Tabah, Pura Puncak Bukit Sinunggal, Virgin Mary Cave, Penegil Dharma temple, Pura Bukit Dulang, Pura Ponjok Batu, Old Village Sembiran, Made Art Studio, Making ingka Sambirenteng, palm sugar Sambirenteng, Village Tejakula, Crafts Banana in Ambengan Village, Monument Triyudha sakti, Silversmith Tirta Prapen, Pura Pejenengan Kibarak Panji Sakti, Pura Bhuana Kerta, Brahma Vihara Arama Banjar, Bamboo Craft Tigawasa, Old Village Pedawa, Tomb Jayaprana, Pura Menjangan, Environment Temple Melanting, Environmental Pura Kerta Wire, Pura Maggots, Parahyangan Betara Wawu, Silversmith and Gold Petemon, Craftsman Weaving Petemon, Pura Jaya Prana Kalianget, Wayang Wong, Games Megoak-goakan, Arts Genjek, Arts tetabuhan, Art Matembang, art Kebyar Gong, Gong Angklung art, Art Gender, Puppet Arts, Crafts and Art Joged Tabuh Angklung (Widiastini, Nyoman Dini Andiani and Trianasari, 2012).

Based on the findings in the field, there are three cultural resources which is Buleleng community arts very potential to be developed into a tourist attraction that genjek, jogged and megoak-goakan game. Th three arts are not sacred arts, so they are good to be used and packed into a tourist attraction that reperesents uniquenes and reflects the identity of Buleleng. In addition, the availability of a representative staging for the arts such as Ex Buleleng harbour and Puri Agung (Agung palace) Singaraja, the packaging art into the calendar of events will greatly help the development of alternative tourism in Buleleng. Ex Buleleng harbour in addition has a large area to be used as a staging place, the place also has a history as the main entrance of the first capital in Bali before transferred to Denpasar. Foreign artists such as Walter Spies, Rudolf Bonnet and others that through his visit had implications for the development of tourism in Bali, used Ex Buleleng Harbour as their entrance into Bali. While Puri Agung Singaraja in addition has a history associated with kingdom in Buleleng also has a representative to be used as a place to hold art. Even the literary works produced by the last king of the Anak Agung Panji Tisna also deliver the name of Puri Agung Buleleng to foreign countries.

Utilization of cultural resources as an alternative tourism should be done carefully so that the purpose of alternative tourism that can be perceived advantage in the long term and does not cause negative impacts, the implementation is to be completely in accordance with the existing concept in alternative tourism. The notion [6] Butler (1992) and [7] Weaver (1993) in (Weaver and Lawton, 1999: 15) on the characteristics of alternative tourism can be used as a reference in the development of alternative tourism in Buleleng, as presented in Table 2 below.

Table 2. Characteristic of Alternative Tourism

\begin{tabular}{lll}
\hline No & \multicolumn{1}{c}{ Characteristic } & \multicolumn{1}{c}{ Deliberate Alternative Tourism } \\
\hline 1 & Market & Allocentric - midcentric \\
& Segment & Low; individual arrangement \\
& Volume and mode & No distinct seasonality \\
& Seasonality & No dominant market \\
& Origins & \\
2 & Attractions & \\
& Emphasis & Moderately commercialized \\
& Character & Area specific, 'authentic' \\
Orientation & Tourist \& local \\
Accommodation & \\
Size & Small-scale \\
Spatial pattern & Dispersed throughout area \\
Density & Low density \\
Architecture & Vernacular style, un-obtrusive, complementary \\
Ownership & Local, small businesses \\
Economic Status & \\
Role of tourism & Complements existing activity \\
Linkages & Mainly internal \\
Leakages & Minimal \\
Multiplier effect & High \\
Regulation & \\
Control & Local 'community' \\
Amount & Extensive; to minimize local negative impacts \\
& Ideology emphasis & Public intervention, community stability \& well- \\
& &
\end{tabular}


Seeing the characteristics listed in Table 2 can be understood that the role of the community is very important, even in the regulation, control of the local community to participate overseeing the development of alternative tourism. In the context of this community as the system would adapt to the changes that occur in the area developed into a tourist destination for the objectives to be achieved in the development of tourism can be beneficial both to the current generation of tourism activities carried out and for the next generation. Neither tourism as a system and society is an integral part of the tourism, the tourism and the public should have the same mission and vision.

Borrowing ideas in [8] Wirawan Ritzer (2012), there is a feature of the system, namely: (1) systems tend to have the properties of order, and the parts are interdependent; (2) the system tends towards selfmaintaining order, or balance; (3) the system becomes static; (4) the characteristics of the part of the system has its impact on other parts; (5) the allocation and integration of two fundamental processes are given-state of equilibrium systems; (6) systems tend to maintain themselves and tend to change the system from within. Understanding the characteristics of the proposed system in [6] Wirawan Ritzer (2012), then tourism and society as a whole are difficult to separate must be able to work together well to produce benefits for all parties involved in the tourism. However, based on the findings in the field conditions of the people tend to be less able to adapt well due to various factors that lead to people less able to manage their resources into a tourist attraction. As stated by [1] Woodley in Ardika (2015) related to the weakness of the public as follows. "Local people have a number of obstacles in the development of tourism, among others: (1) Local communities often lack even do not have a vision or understanding of tourism development. (2) Low interest (interest) and local public awareness on tourism, because it is considered to be something that comes from outside their culture. (3) The quality of human resources (HR) owned by local communities are generally limited in the field of tourism. (4) The gap of culture (cultural barrier) between local people and tourists are often different from each other. (5) Economic and investment factors are decisive in the development of the tourism industry is often not owned by the local community (Woodley, in Ardika, 2015) ".

Having many advantages, then the public should be given guidance and training to enable them to adapt well to the changes brought about by the tourism. In evolution, Greenwood in [9] Pitana (2005) explains that the relationship between tourists and local communities leads to the commoditization and commercialization, so that before somewhere developed into a tourist destination needs to understand the adaptability of people both on the social, cultural, economic, environmental and politically. It is very important to do for the development of alternative tourism, especially those utilizing cultural resources as tourist attraction can work well, especially against the culture of the people that are sacred as sacred dance or a temple ceremony that has a certain value. It is important to remember the sacred nature of culture can indeed make Bali including Buleleng has a different tourist visits to tourism elsewhere, ie, adjusted to a religious activity conducted by the Hindu community of Bali.

In the application, so that the development of alternative tourism in Buleleng by utilizing cultural resources can be done well there are a few things to do include: (1) Understanding the type of culture that is both sacred and profane. This is important so that sacred art can be maintained as a result of the demand of tourists and a travel agency, but a society that set time visits by tourists accompanied by rules that exist in the community norm both oral and written; (2) Scheduling cultural staging activities that can be offered a year before they are carried (calendar of events), so that tourists can set the time to visit a certain place with the aim of seeing and knowing the culture that is owned by the venue; (3) Promoting Tourism District by utilizing local arts such as dance icon: megoak-goakan which is a type of dance typical of Buleleng regency which has common values. Through art and unique packaging is not known as sacred, it is expected Buleleng as a tourist destination will be unique and different from other tourist destinations, so it is worth to be visited by all tourists both domestic and foreign tourists.

\section{Education-Based Capital Local Human Resources in the Development of Tourism Buleleng}

International tourism organizations namely The World Tourism Organization (2005) defines sustainable tourism as follows : "Sustainable tourism development guidelines and management practice are applicable to all forms of tourism in all types of destinations, including mass tourism and the various niche tourism segments. Sustainability principles refer to the environmental, economic, and socio cultural aspects of tourism development and a suitable balance must be establishment between these three dimensions to guarantee its long-term sustainability. Thus, sustainability tourism should: 1) Make optimal use of environmental resources that constitute a key element in tourism development, maintaining essential ecological processes and helping to conserve natural resources and biodiversity; 2) Respect the 
socio cultural authenticity of host communities, conserve their built and living cultural heritage and traditional values and contribute to their-cultural understanding and tolerance; 3) Ensure viable, long term economic benefits to all stakeholders that are fairly distributed, including stable employment and income earning opportunities and social service to host communities and contributing to poverty alleviation".

The above explanation can be understood that the principles of sustainable tourism development must consider the various aspects of the environmental, cultural, economic, social. Sustainable tourism should: 1) Utilize environmental resources as a key element in tourism development, maintaining ecological processes essential and helping to conserve natural resources and biodiversity, 2) Respect for cultural authenticity social host communities, conserve their built and living cultural heritage and traditional values, and contribute to their cultural understanding and tolerance; 3) Ensuring that communities received economic benefits. Thus, in the development and management of tourism, should pay attention to local resources both natural resources, cultural resources and human resources, which in exploiting the resources, the people must obtain positive benefits, especially the economic field. Obviously, this can be achieved by empowering individuals who are able to utilize the potential of becoming perpetrators themselves who understand the needs of tourism and tourist motivation and able to provide tourism services are professional, but still keeping the social and cultural values it has.

The development of an area into a tourist attraction is not an easy matter. However, the government can work together with local communities to develop the existing tourism in the area, where the first step can be done by utilizing local labor in the area. This is important because the community as part of that is in the area of tourism must necessarily be given the opportunity to get the benefits of social, economic, culture, environment and politic. To generate local energy actors that are ready to be of service in tourism, besides of course the government to cooperate with the investors in order to improve the quality of local resources, the government should also pay attention to the ability and needs of the community. In this context, educational background and culture of the community must be considered well, in order to educate the public be given to the proper and precise manner.

Soekanto (1990) states that local communities are as follows: "The local community is a member members of a group, whether it is large or small groups, living together in such a way that they feel that the group is able to meet the needs - the main purpose of life". Further mentioned elements of the local community is a sense of sympathetic, camaraderie and mutual need among individuals who are members of the local community who feel themselves dependent on their community. Departing from the concept of the equality and interdependence with one another, then a form of education whether it be coaching, education and training should be adjusted to the values that exist in society as well as the skills they possess. Such as when people have good skills in making snacks Bali using traditional materials and equipment, then it should be given education which is aimed at improving hygiene, fix the appearance as well as teach you how to communicate in a foreign language which is related to the field that will be practiced.

Education provided to the public is essential with the aim of creating a society that is able to interact with both the stakeholders of tourism in their area. Nandi (2008), which explains that the tourism education is one of the key in the development of tourism as the region requires skilled labor that must be developed continuously. Furthermore [10] Warsitaningsih in Nandi (2008) describes the criteria for major tourism workforce that is: 1) Development of knowledge about the procedures for servicing associated with the variation of tourism activities, such as hotel services, in contrast to the ministry in place or in your tour. 2) Development of knowledge of the equipment and supplies needed in service 3) Development of human resources related to the development of attitudes, behavior, manners, and so forth. Society as the owner of the area certainly deserves a chance to interact with tourists, both in terms of communicating and selling local products. In this context, the development of tourism in a tourist destination that involves community participation, the need for guidance to the public before the holidays developed. Pitana 2006 reveals there are three components that must exist, that community participation can run well, namely: 1) Enabling settings, namely strengthening condition, situation at the local level to be good, so that local communities can be creative. Supposing make a good stage, so that local people can dance on the stage. 2) Empowering local community. Once there is a stage to dance the local community must be upgraded their skill to dance. This means that after the local setting is prepared, the local community should be given the knowledge and skills so as to utilize the settings properly. This is partly done through education, training and various other forms of human resource development.m 3) Sociopolitical support. If the stage has been good, the local community has been able to dance, hence the need for other supporting devices, such as equipment, spectators and so on, which no other form of social support, politics, networking, and so on. Without adequate social support policy, local communities can not dance well in stage although the real smart people dancing. 
Above Pitana's explanation (2006 ) gives an understanding that a form of education for local communities whose land was developed as a tourist destination to go through the stages related to physical and mental readiness of society, and thus education provided will be useful in the long term. Borrowing ideas in Zubaedi Chambers ( 2013) explained that community development is a concept that summarizes the economic development of social values, which are reflected in the concept of a new paradigm of development that is both empowering and sustainable. Based on this, the synergy between the government and local communities in Buleleng region could become a model of sustainable tourism development that will give welfare for society.

Borrowing the idea of [5] Adi (2012), there are two methods of approach that can be done to develop the ability of the community directive approach (instructive) and non-directive approach (participatory). The approach in question is as follows: 1. Directive Approach carried out based on the assumption that the community worker knows what is needed and what is good for society. This kind of approach can be used when people did not understand about matters related to tourism, which can be proved through socio-demographic stating that their educational background nobody ever received education about tourism, or just graduated from elementary or middle school. In practice, community worker already should give you a good understanding and correct on tourism, so that people can understand well the meaning and purpose of tourism, for themselves, their environment and other relevant parties in tourism. Community worker in practice must uphold honesty and values that exist in the community, so that things which are given to the community will not lead society toward an annoyance or antagonism that can eventually lead to conflict, but rather lead people to be able to be apathy so that all parties involved in it can benefit the same, be it in economic, social, cultural, political, and environmental. 2. The non-directive approach (participatory) is performed based on the assumption that people know what they really need and what is good for them. On this approach, worker community who are key actors in society change is society itself, so in this case worker community should help people to be able to explore and develop their potential. In this case, the public is given the opportunity to understand the potential the needs for them. So that the worker can help the community in making analysis and decision-making that is useful for their own purpose they want.

\section{Utilization Cultural Implications for Travel Products}

Making culture as tourist product certainly has implications both positive and negative. In order to minimize the negative implications, the need for control systems at each stage of the development of tourism involves government, business community, community leaders and academics. Therefore in tourism development should be, there are four important pillars that must play an active role and responsible for tourism which will be built and developed namely: (1) the government acting as a regulator firm, (2) tourism businesses act as investor wise and prudent, (3) The society acts as a good host and friendly, and (4) educational institutions / academia role is to provide guidance and training for people to be able to act as professional actors of tourism services.

Implications in any tourism development, including in alternative tourism can occur in economic, social, cultural, environmental and political. Tourism as a multi-industry opportunities will certainly have an impact on the emergence of various businesses related to tourism, both directly and indirectly. In general, the economic implications arising from the existence of the foreign exchange earnings of tourism is, employment, development and government revenue (Cohen, 1984). Implications of tourism on the economic aspects tend to be positive, despite the frequent inequality for those who have big capital capital with small capital. Borrowing ideas Plummer (2011) argues that there are seven capital resources within statifikasi life, namely: (1) economic resources, (2) social resources, (3) cultural resources, (4) resources symbolic, (5) political resources, (6) the body and emotional resources, (7) the personal resources or specificity that is owned by someone either the knowledge, skills and abilities. The Seven capitals have very important role in a person's job position in tourism. The more numerous and powerful capitals it has, then the better position their work, and also to the economic implications that obtained.

Tourism as an industry or a complex system can certainly have implications on the socio-cultural life of the community, the environment is used as an area for development of tourism and politics in a tourist destination as a form of struggle for meaning space. It is something of a dilemma when tourism built and developed in a region, economically can provide positive implications, but it can also be negative implications for the social and cultural aspects. As stated by [11] Greenwood in Pitana and Gayatri (2005) that tourism has a huge impact on vertical mobility. Economic development caused by tourism causes the growth of new middle classes, which always exist in a situation of competition with the middle class who have been there before. While de Kadt in Pitana and Gayatri (2005) emphasize that the presence of tourism social stratification based on old values, such as birth or blood, switch to a new stratification base, which prefers economic aspects. 
More tourism is seen as the arrival of the advantage of money causes all the parties involve economically, socio-cultural, environmental and political meaning. The formation of social classes in society that occurred as a result of tourism caused by the lifestyle of people who want to show status and his identity in the course society distinguished by their stability at the work is practiced. In the sociocultural aspects, the development of tourism in a region often leads to commoditization and commercialization of the cultural community. Thought which always put the interests of tourists and consider it a noble because people are willing to commercialize culture. For example Barong dance and dance Sanghyang which actually means a sacred dance has now been staged in a place not only to duly fulfill the desires of tourists. The phenomenon will certainly erode cultural values of society, so that tourists consider the community is very easy to buy. Based on this phenomenon, should be the development of tourism should pay attention to the values and norms that exist in society, so that before the development of tourism in the community are doing in an area should be given direction with different approaches to things that are not managed profane sacred. In this context, of course the government must firmly implement the principles of cultural tourism is implicitly supposed safeguard cultural values - not reducing by making profane tourism product.

The development of tourism in Bali implicitly indeed protect the culture as contained in Regulation Nomor 3 of 1991, Article 2, which states that the objectives of cultural tourism is to introduce, utilize, conserve and improve the quality of objects and tourist attraction, maintain norm and cultural values and religious life of Bali nature of environmentally, prevent and counteract the negative effects that can be caused by tourism activities (Ardika, 2003). This regulation should be maintained, either implicitly or explicitly that the preservation of the values of the Balinese culture can be carried out. Although the latest Regulation namely Regulation no. 2 of 2012 on article 3 was changed to the purpose of tourism culture of Bali aimed to (1) preserving Balinese culture animated by the values Hinduism, (2) increase economic growth, improve people's welfare, (3) create business opportunities, (4) creating employment, (5) preserve nature, environment and resources, (6) lift the image of the nation, (7) strengthen patriotism and unity of the nation, and (8) strengthening the friendship between nations, the application preservation of culture remains to be done to remember Bali is nothing more than a living museum because the culture in everyday society.

\section{Conclusions}

Alternative tourism that has a vision and a mission to fix the model of mass tourism has an impact on the occurrence of damage to the various aspects of community life should be implemented well by the pillars of the government's tourism, tourism businesses, communities and educational institutions. Local governments at the Bali Provincial Regulation No. 2 of 2012 Article 2 Oneness that Balinese culture animated by the values of Hinduism must be preserved, it should not only preserve tourism players, but also preserve the things that are sacred. Through the development of alternative tourism which is based on the criteria outlined in Table 1 and Table 2, in fact capable of providing protection against the culture of the people because in addition the developer is done in stages by taking into account various aspects in it, alternative tourism is a type of tourism that explore and manage the potential optimally -not maximum. Therefore, by using this type of alternative tourism, tourism in Buleleng can develop well and beneficial in the long term.

\section{References}

Ardika, I Wayan. (2003). "Pariwisata Bali: Membangun Pariwisata-Budaya dan Mengendalikan BudayaPariwisata. Dalam Bali Menuju Jagadhita: Aneka Perspektif. Nyoman Dharma Putra (ed). Denpasar: Pustaka Bali Post.

Christous, Loizos. (2012). Is it Possible to Combine Mass Tourism with Alternative Forms of Tourism: The Case of Spain, Greece, Slovenia and Croatia. Journal of Business Administration Online-Spring.

Shafaei, Fatemeh dan Mohamed, Badaruddin. (2015). A Stage-Based Model Development Study on Tourism Social Impact Assessment. International Journal of Scientific and Research Publication, Volume 5, Issue 3.

Robinson, H.A. (1979). Geography of Tourism, MacDonald \& Evans.

Adi, Isbandi Rukminto. (2012). Intervensi Komunitas dan Pengembangan Masyarajat Sebagai Upaya Pemberdayaan Masyarakat. Jakarta: PT. Raja Grafindo Persada. 
Butler, R.W dan L.A Waldbrook. (1991). “A New Planning Tool; The Tourism Opportunity Spectrum.” The Journal of Tourism Studies Vol. 2 No.1

Weaver, David dan Lawton, Laura. (1999). Sustainable Tourism: a Critical Analysis. Coopertaive Research Center for Sustainabel Tourism. Research Report Series. CRC for Sustainable Tourism Pty Ltd.

Wirawan, I.B. (2012). Teori-teori Sosial Dalam Tiga Paradigma Fakta Sosial, Definisi Sosial dan Perilaku Sosial. Jakarta: Kencana.

Pitana. (2005). Sosiologi Pariwisata. Yogyakarta : Andi.

Nandi. (2008). Pariwisata dan Pengembangan Sumberdaya Manusia. Jurnal GEA Jurusan Pendidikan Geografi Vol. 8 No.1 APRIL 2008

Pitana, Gde dan Gayatri, Putu G. (2005). Sosiologi Pariwisata. Yogyakarta: Andi. 